\title{
Aplikasi Bacillus sp Pada Produksi Enzim Menggunakan Metode Fermentasi Padat - Review
}

\author{
Siti Maftukhah \\ Jurusan Teknik Kimia, Fakultas Teknik, Universitas Islam Syekh-Yusuf, Jl. Maulana Yusuf No.10 Tangerang Banten \\ 15118, Indonesia \\ sitimaftukhah@unis.ac.id
}

\begin{abstract}
Solid State Fermentation (SSF) is considered the most beneficial method of fermentation than Submerged Fermentation (SmF). This is because the solid fermentation (SS) method is more environmentally friendly, higher fermentation productivity, higher product concentration and stability, lower catabolic suppression, implantation of microorganisms specifically for insoluble substrates and also lower sterility activities due to water activity used is very low. Bacillus sp can be used for enzyme production. This paper reviews the application of solid fermentation (SSF) for enzyme production, namely amylase, esterase, xylanase, pectinase and likenase by Bacillus sp. In the production of enzymes that use Bacillus sp is Bacillus cereus which produces the amylase enzyme, Bacillus sp. JB-99 which produces the xylanase enzyme, Bacillus licheniformis which produces the lycenase enzyme, Bacillus altitudinis AP-MSU which produces the esterase enzyme, Bacillus sp. DT7 produces pectinase enzymes, and many Bacillus sp by solid fermentation processes that produce enzymes.
\end{abstract}

Keywords: Amylase, Bacillus sp, Esterase, Likenase, Pectinase, Solid fermentation, Xylanase

\begin{abstract}
Abstrak. Solid State Fermentation (SSF) atau fermentasi padat dianggap sebagai metode fermentasi yang paling menguntungkan dari pada Submerged Fermentation (SmF) atau fermentasi terendam. Hal ini dikarenakan bahwa metode fermentasi padat (SS) lebih ramah lingkungan, produktivitas fermentasi yang lebih tinggi, konsentrasi produk dan stabilitas yang lebih tinggi, penekanan katabolik yang lebih rendah, penanaman mikroorganisme khusus untuk substrat yang tidak larut dan juga aktifitas sterilitas yang lebih rendah karena aktivitas air yang digunakan sangat rendah. Bacillus sp dapat digunakan untuk produksi enzim. Makalah ini mengulas aplikasi fermentasi padat (SSF) untuk produksi enzim yaitu amilase, esterase, xilanase, pektinase dan likenase oleh Bacillus sp. Dalam produksi enzim yang menggunakan Bacillus sp adalah Bacillus cereus yang menghasilkan enzim amilase, Bacillus sp. JB-99 yang menghasilkan enzim xilanase, Bacillus licheniformis yang menghasilkan enzim likenase, Bacillus altitudinis AP-MSU yang menghasilkan enzim esterase, Bacillus sp. DT7 menghasilkan enzim pektinase, dan banyak Bacillus sp dengan proses fermentasi padat yang menghasilkan enzim.
\end{abstract}

Kata kunci : Amilase, Bacillus sp, Esterase, Fermentasi Padat, Likenase, Pektinase, Xilanase

\section{Introduction}

Fermentasi padat (SSF) sangat berpotensi untuk produksi enzim. Hal ini dapat menjadi perhatian khusus karena produk fermentasi mentah dapat digunakan secara langsung sebagai sumber enzim. Selain aplikasi konvensional dalam industri makanan dan fermentasi, enzim mikroba telah mencapai peran penting dalam biotransformasi yang melibatkan media pelarut organik, terutama untuk senyawa bioaktif (Pandey, 1999). Produksi enzim menggunakan fermentasi terendam (SmF) sudah lebih dari satu abad diaplikasikan dibandingkan dengan fermentasi padat. Ada beberapa yang menguntungkan dengan menggunakan fermentasi $\mathrm{SmF}$ ini. Sistem SmF lebih mudah untuk direkayasa oleh para peneliti karena kemudahan kontrol proses dan sterilisasi. Selain itu, produksi enzim dapat bersifat konstitutif atau diinduksi dan menunjukkan pola produksi yang berbeda, tergantung pada strain dan kondisi kultur. Tetapi, proses SSF memiliki beberapa keunggulan dibandingkan proses $\mathrm{SmF}$, meskipun proses ini hanya ada di tingkat laboratorium. Ini juga didukung oleh Wang dan Chen 2009, yang menyatakan bahwa kultur berbasis adhesi permukaan lebih produktif daripada SmF. Beberapa kelebihan SSF adalah produktivitas fermentasi yang lebih tinggi, konsentrasi produk dan stabilitas yang lebih tinggi, penekanan katabolik yang lebih rendah, penanaman mikroorganisme khusus untuk substrat yang tidak 
larut dan juga aktifitas sterilitas yang lebih rendah karena aktivitas air yang digunakan rendah (Ashis, et al., 2008).

Sejumlah besar mikroorganisme, termasuk bakteri, ragi dan jamur menghasilkan berbagai kelompok enzim. Pemilihan strain tertentu bukan hal yang mudah, terutama ketika produk enzim yang kompeten secara komersial harus dicapai. Pemilihan strain yang cocok untuk tujuan yang diperlukan tergantung pada sejumlah faktor, khususnya pada sifat substrat dan kondisi lingkungan (Pandey, 1999).

Faktor utama yang mempengaruhi sintesis mikroba enzim dalam sistem SSF meliputi: pemilihan substrat dan mikroorganisme yang sesuai, pretreatment dari substrat, ukuran partikel (ruang antar-partikel dan luas permukaan) dari substrat, kadar air dan aw substrat, kelembaban relatif, jenis dan ukuran inokulum, kontrol suhu bahan fermentasi / penghilangan panas metabolik, periode penanaman, pemeliharaan keseragaman dalam lingkungan sistem SSF, dan atmosfer gas, yaitu tingkat konsumsi oksigen dan laju evolusi karbon dioksida (Ponnuswamy, et al., 2015).

Bacillus sp adalah genus bakteri grampositif berbentuk batang dan anggota filum firmicutes. Spesies Bacillus sp dapat berupa aerob obligat (bergantung oksigen), atau anaerob fakultatif (memiliki kemampuan aerobik atau anaerob) (Ponnuswamy et al 2015).

\section{Metode dan Pembahasan}

Aplikasi Bacillus sp dalam produksi enzim dengan metode SSF adalah sebagai berikut :

\section{II.1 Enzim Amilase}

Famili enzim amilase telah dianggap baik melalui studi berbagai mikroorganisme. Kehadiran dua kelas utama enzim pendegradasi pati ini telah diidentifikasi yaitu pertama $\alpha$-amylase (endo-1,4$\alpha$-D-glucan glucohydrolase, EC-3.2.1.1) yang secara acak memecah ikatan 1,4- $\alpha$-D-glucosidic antara unit glukosa yang berdekatan dalam rantai amilosa linier, dan kedua glukoamilase (sinonim amiloglukosidase) yang juga disebut sebagai enzim glukogenik, glukogenase pati, gamma amylase (exo-1,4- $\alpha$-D-glucan glucanohydrolase, EC3.2.1.3) yang menghidrolisis unit glukosa tunggal dari ujung amilosa dan amilopektin secara bertahap. Tidak seperti $\alpha$-amilase, sebagian besar glukoamilase juga mampu menghidrolisis 1,6- $\alpha$ ikatan di titik percabangan amylopectin, meskipun pada tingkat yang lebih lambat dari 1,4-ikatan (R.S.Prakasham, et al., 2006).

Enzim amilase diproduksi oleh berbagai mikroorganisme, termasuk bakteri, jamur dan ragi (yeast). Satu strain tunggal juga dapat menghasilkan enzim amilase dengan baik. Enzim ini telah diaplikasikan di industri makanan olahan, teknologi fermentasi, industri tekstil dan kertas, dll.
SSF telah digunakan untuk produksi $\beta$-amilase memproduksi enzim amilase. Sebuah studi yaitu Ray, et al., 1997 membandingkan EC-3.2.1.2 dari limbah pati oleh strain hyper-amylolytic dari Bacillus megaterium B6 mutan UN12 menggunakan proses SmF dan SSF. Limbah tepung yang digunakan sebagai substrat berasal dari arum, jagung, kentang, kacang-kacangan, beras, sekam padi, asam, kernel, singkong, kastanye, kastanye air, gandum dan dedak gandum. Arum dan dedak gandum memberikan hasil yang paling tinggi (Ponnuswamy, et al., 2015).

\section{II.2 Enzim Esterase}

Enzim esterases (EC 3.1.1.3, carboxyl ester hidrolase) adalah satu dari beragam kelompok hidrolase yang mengkatalisasi pembelahan dan pembentukan ikatan ester dan secara luas didistribusikan pada hewan, tanaman, dan mikroorganisme (Bornscheuer, 2002). Enzim esterase dan lipase adalah kelas enzim hidrolitik yang mengkatalisis hidrolisis ikatan ester dalam media organik. Enzim esterase dan lipase mengkatalisasi reaksi seperti esterifikasi, interesterifikasi dan transesterifikasi. Tetapi enzim esterase berbeda dari lipase terutama berdasarkan spesifisitas substrat (Palanichamy, et al., 2012). Selain itu, enzim lipase lebih suka substrat yang tidak larut dalam air, biasanya trigliserida yang terdiri dari asam lemak rantai panjang. Sedangkan esterase secara istimewa menghidrolisis ester sederhana (seperti etil asetat) dan biasanya hanya trigliserida yang mengandung asam lemak lebih pendek dari C6 (Bornscheuer, 2002). Enzim esterase saat ini digunakan dalam berbagai aplikasi industri, seperti pemrosesan kimia organik, formulasi deterjen, biosurfaktan dan industri kimia. Harga dari enzim esterase adalah mahal sehingga kondisi produksi akan sangat membantu untuk penggunaan enzim ini secara luas. Dalam produksi enzim esterase, mikroorganisme dan jenis esterasenya, disarankan untuk dipilih metode fermentasi yang tepat (Palanichamy, et al., 2012). Enzim ini dapat diproduksi dengan menggunakan fermentasi padat atau terendam. Strain Bacillus altitudinis $A P-M S U$ dapat digunakan untuk menghasilkan enzim esterase, yang diisolasi dari usus Sardinella longiceps yang dikumpulkan dari pantai Colachel dengan mengikuti metode yang dijelaskan oleh Arbaciauskiene, et al., 2006. Bacillus altitudinis AP-MSU menghasilkan zona bening ketika diratakan dengan agar sprit blue $(\mathrm{g} / \mathrm{l})$ (Hiveg hydrolyzate, 10; ekstrak ragi, 5.0; sprit blue, 0,15; agar, 17) disuplai dengan Tween 80 setelah 48 jam inkubasi, dan diidentifikasi sebagai $B$. altitudinis berdasarkan analisis urutan gen $16 \mathrm{~S}$ RNA (Arbaciauskiene, et al., 2006).

\section{II.3 Enzim Xilanase}


Xilanase adalah enzim yang dihasilkan dari xilan. Xilan paling banyak dari hemiselulosa, yang terletak di dinding sel kayu keras dari semua tanaman yang berlimpah dalam jaringan yang telah mengalami penebalan sekunder (S. Virupakshi, et al., 2005). Xilan adalah polisakarida heterogen yang terdiri dari residu $\beta-1,4 D$-xylosyl pada ikatan belakang tetapi juga mengandung asam arabinosa, asam glukuronat dan asam arabinoglukuronat yang dihubungkan dengan ikatan D-xilosa. Karena heterogenitas, xilan memerlukan dua aktivitas enzim yang berbeda untuk hidrolisis yaitu $\beta-1,4$ endo - xilanase (EC.3.2.1.8) dan $\beta$ - xylosidase (EC 3.2.1.37), yang bertanggung jawab untuk hidrolisis rantai utama, serangan pertama terhadap hubungan rantai utama internal dan pelepasan residu xilosil dan yang kedua melepaskan sisa xylosil oleh serangan xylooligosaccharides (Bakir, et al., 2001).

Enzim xilanase yang bebas selulase barubaru ini menarik perhatian karena aplikasi potensialnya sebagai zat pemutih dalam industri pulp dan kertas. Ada beberapa laporan tentang produksi enzim termasuk xilanase oleh fermentasi padat. Berbagai mikroorganisme termasuk bakteri, ragi dan jamur berfilamen telah dilaporkan menghasilkan enzim xilanolitik dan enzim xilanolitik ini juga diketahui terjadi pada bakteri rumen dan protozoa (S.Virupakshi, et al., 2005). Bacillus sp. JB-99 digunakan untuk produksi xilanolitik sebagai strain bakteri. Aplikasi potensial enzim xilanase tanpa celulase, termasuk yang ada di industri kertas karena aktivitas selulase berdampak buruk pada kualitas bubur kertas. Aplikasi spesifik termasuk produksi pulp selulosa dan pretreatment pulp untuk meningkatkan proses pemutihan. Xilanase juga telah ditemukan pada aplikasi dalam biokonversi lignoselulosa menjadi gula, etanol dan zat bermanfaat lainnya, pemisahan jus dan anggur, ekstraksi minyak nabati, kopi dan pati dan peningkatan nilai gizi dari silase dan green feed (Kulkarni, et al., 2001).

\section{II.4 Enzim Pektinase}

Produksi enzim oleh SSF menggunakan bakteri Bacillus sp telah dilaporkan menghasilkan banyak enzim seperti xilanase dan amylase, tetapi literatur yang melaporkan produksi enzim pektinase oleh SSF menggunakan bakteri Bacillus $s p$ masih kurang. Penggunaan SSF untuk produksi enzim terutama dari jamur mungkin karena kepercayaan umum bahwa teknik SSF hanya berlaku untuk jamur berfilamen. Studi komparatif tentang produksi enzim pektinase oleh Aspergillus $s p$. menggunakan fermentasi terendam $(\mathrm{SmF})$ dan fermentasi padat (SSF) telah menunjukkan bahwa SSF menjadi pilihan yang lebih baik. Selain itu, penggunaan SSF telah dilaporkan lebih menguntungkan daripada $\mathrm{SmF}$ karena memungkinkan biaya produksi lebih murah dari enzim yang memiliki sifat fisiokimia yang lebih baik daripada yang diproduksi oleh $\mathrm{SmF}$ (Des, et al., 2003). Produksi enzim pektinase kondisi alkali dan termotoleran yang sangat tinggi dapat diproduksi menggunakan Bacillus sp mesofilic DT7 menggunakan kondisi SSF. Substrat padat (dedak gandum, dedak beras, apel pomace) dapat digunakan untuk menghasilkan enzim pektinase. Penelitian tentang pemilihan substrat yang cocok untuk produksi pektinase terutama berpusat pada tanaman agro-industri tropis dan residu (Kashyap, et al., 2000).

\section{II.5. Enzim Likenase}

Enzim likenase adalah endo- $\beta-1,3-1,4-$ glukanase yang mengikat hubungan $\beta-1,4$ yang berdekatan dengan ikatan $\beta-1,3$ di likenan atau barley $\beta$-glucan, yang terutama menghasilkan 3-O$\beta$-cellobiosyl- D-glucosa dan 3-O- $\beta$-cellotriosyl-Dglukosa (Fatma et al 2012). Enzim likenase tidak dapat menghidrolisis ulang rangkaian dari glukan berantai (1-3) atau (1-4) seperti laminarin atau karboksimetilselulosa (CMC). Endo- $\beta-1,3-1,4-$ glucanase memiliki aplikasi spesifik dalam industri pembuatan bir di mana enzim ini digunakan untuk menggantikan dan supplemen malting enzim. Faktanya, $\beta$-glukanase dapat mengurangi viskositas dan kekeruhan dalam pembuatan bir, meningkatkan hasil ekstrak dan menghasilkan malt pada pembuatan bir berkualitas tinggi (Celestino, et al., 2006).

Dalam industri pakan ternak, suplementasi enzim ini dapat meningkatkan kecernaan $\beta$-glucan dalam bahan pakan, meningkatkan efisiensi konversi pakan, dan mengurangi masalah sanitasi seperti kotoran yang lengket. Enzim likenase juga digunakan dalam formulasi deterjen untuk menghilangkan $\beta$-glucan atau noda. Enzim likenase diproduksi oleh berbagai mikroorganisme termasuk bakteri, jamur dan juga tanaman tingkat tinggi. Sebagian besar likenase komersial diisolasi dari spesies Bacillus karena Bacillus mempunyai potensi yang tinggi dalam produksi enzim likenase di bawah fermentasi terendam $(\mathrm{SmF})$ seperti strain Bacillus subtilis ZJF-1A5 dan strain Bacillus subtilis crsA47 (Fatma, et al., 2012). Sedangkan produksi enzim likenase yang menggunakan SSF oleh strain bakteri belum ada penelitian yang melaporkan hal tersebut kecuali produksi enzim likenase oleh jamur Trichoderma reesei GXC (Sun, et al., 2002) dan Aspergillus terreus ASKU 10 dan dengan $B$. licheniformis $U E B C$ (Prajanban, et al., 2008).

\section{Kesimpulan}

Bacillus sp digunakan untuk produksi enzim. Dalam produksi enzim yang menggunakan Bacillus sp adalah Bacillus cereus yang menghasilkan enzim amilase, Bacillus sp. JB-99 yang menghasilkan enzim xilanase, Bacillus licheniformis yang menghasilkan enzim likenase, Bacillus altitudinis AP-MSU yang menghasilkan 
enzim esterase, Bacillus sp. DT7 menghasilkan enzim pektinase, dan banyak Bacillus sp dengan proses fermentasi padat yang menghasilkan enzim.

\section{Daftar Pustaka}

Arbaciauskiene, V.S., Sruoga, A., \& Butkauskas, D. (2006). Assessment of Microbial Diversity in the River Trout Salmotrutta fario L. Intestinal Tract Identified by Partial 16S rRNA Gene Sequence Analysis. Fish. Sci, 72, 597-602.

A.Pandey., P. Selvakumar., Carlos. R.S., \& Poonam. N. (1999). Solis-state Fermentation for the Production of Industrial Enzyme. Fermentation-Science \& Tecnology, 77(1), 149-162.

Ashis, K.M., Hemanta, A., \& Sudhir, K.R. (2008). Production of Alkaline Protease By A Thermophilic Bacillus subtilis Under Solidstate Fermentation (SSF) Condition Using Imperata cylindrica Grass and Potato Peel As Low-cost Medium: Characterization and Application of Enzyme in Detergent Formulation. Biochemical Engineering Journal, 39, 353-361.

Bakir, U., Yavascaoglu, S., Guvenc, F., \& Ersayin, A. Anendo- $\beta-1,4$-xylanase from Rhizopus oryzae: production, partial purification and biochemical characterization. Enz Microb Technol 2001;29:328-34.

Bornscheuer, Y.T. (2002). Microbial Carboxyl Esterases: Classification, Properties and Application in Biocatalysis. FEMS Microbiol, 26, 73-81.

Celestino, K.R.S., Cunha, R.B., \& Felix, C.R. (2006). Characterization of a $\beta$-glucanase Produced by Rhizopus Microsporus var. Microsporus, and its Potential for Application in the Brewing Industry. $B M C$ Biochem. 7, 23.

Des, R.K., Sanjeev, K.S., \& Rupinder, T. (2003). Enhanced Production of Pectinase by Bacillus sp. DT7 using Solid state Fermentation. Bioresource Technology, 88, 251-254.
Fatma, C., Amel, K., Fatma, B., Monia, B., Raoudha, E., \& Semia, E.C. (2012). Statistical Optimization for the Production of Lichenase by a Newly Isolated Bacillus licheniformis UEB CF in Solid state Fermentation Using Pea Pomace as a Novel Solid Support. Industrial Crops and Products, 40. 192-198.

Gessesse, A., \& Mamo, G., (1999). High Level Xylanase Production by an Alkalophilic Bacillus sp. by Using Solid state Fermentation. Enzyme Microb Technol. 25, $68-72$.

Kulkarni, N., Shendye, A., \& Rao, M. (1999). Molecular and Biotechnological Aspects of Xylanases. FEMS Microbial, 23, 41-456.

Palanichamy, E., Rajamony,U., Arunachalam, P., \& Grasian, I. (2012). Solid-state Production of Esterase Using Fish Processing Wastes by Bacillus altitudinis AP-MSU. Food and bioproducts processing, 90, 370-376.

Ponnuswamy, V., M. Kalaiyarasi., \& Samuel, G. P. V. (2015). Cow Dung is an Ideal Fermentation Medium for Amylase Production in Solid-state Fermentation by Bacillus cereus. Journal of Genetic Engineering and Biotechnology, 13, 111117.

Prajanban, J., Thongkhib, C \& Kitpreechavanich, V. (2008). Selection of High $\beta$-glucanase Produced Aspergillus Strain and Factors Affecting the Enzyme Production in Solid state Fermentation. Kasetsart J. (Nat. Sci.) 42, 294-299.

Ray, R, R., Jana, S. C., \& Nanda, G. (1997). Indian J. Expt, Biol, 35, 285 -288.

R.S.Prakasham., Ch. Subba. R., \& P.N. Sarma. (2006). Green Gram Husk - an Inexpensive Substrate for Alkaline Protease Production by Bacillus $s p$. in Solid-state Fermentation. Bioresource Technology, 97, 1449-1454.

S.Virupakshi., K. Gireesh. B., Satish. R. G., \& G.R. Naik. (2005). Production of a Xylanolytic Enzyme by a Thermoalkaliphilic Bacillus sp. JB-99 in Solid state Fermentation. Process Biochemistry, 40, 431-435. 